\title{
Repeated Elections and Opposition Challenges in Malaysia
}

\author{
Yukiko Taniguchi*
}

\begin{abstract}
Malaysia was a typical example of authoritarian regimes that strengthened the regime through elections for a long time until 2018, but street protests, in which the masses participated on a large scale, have become more active since 1998. Nevertheless, the opposition groups had been challenging the regime through elections and had never tried overthrowing it through the protests. Why was the choice made, and by what mechanism? This paper explores these questions and focuses on the impact of repeated elections on these opposition's changing strategic options. It argues that repeated elections not only strengthened the ruling party's support base but also long moderated mass protests in Malaysia while providing the opposition parties with electoral experience and facilitating coalition formation. That was brought about by the transformation of protests as a means of generating mass discontent against the regime and mobilizing support for the opposition, rather than directly challenging it.
\end{abstract}

\footnotetext{
"I thank discussants and participants at the 2019 American Political Science Association AsiaPacific Workshop and the 2019 Japanese Association for Comparative Politics. Financial support from the Japan Society for the Promotion of Science (19K20876) and The Ryoichi Sasakawa Young Leaders Fellowship (2017-2018) is gratefully acknowledged.

* Ph.D. Candidate, Graduate School of Political Science, Waseda University, Japan. Research Associate, Institute of Developing Economies, Japan External Trade Organization. E-mail: yukikot.1538@,fuji.waseda.jp.
} 


\section{Introduction}

Malaysia, long dominated by the United Malays National Organization (UMNO)-led Barisan Nasional (National Front: BN) regime and referred to as a typical example of competitive authoritarian regimes, ${ }^{1}$ has seen a growing number of mass street protests since 1998. In particular, the Coalition for Clean and Fair Elections (Bersih), a movement for electoral reform, has led to massive demonstrations in Kuala Lumpur since 2007. In the 2015 demonstrations, 250,000 people were mobilized at the peak according to the estimation by organizers. ${ }^{2}$ However, the $\mathrm{BN}$ regime did not democratize by these protests and ended with the opposition' victory in the 2018 general elections. As will be discussed below, the oppositions did not necessarily perceive elections as the only legitimate means to achieve the regime change from the early days of Malaysia's independence. There must have been a change in the opposition's strategic options in the period leading up to the regime change by the election.

This paper focuses on the repetition effect of elections as a factor in the change in opposition's challenges and examines its mechanism through a long-term case analysis of opposition's challenge, mass protests and opposition parties' coordination in Malaysia. Specifically, it argues that repeated elections discourage oppositions from directly challenging the regime through protests, while providing opportunities for opposition parties to learn coordinating through the experience of participating in elections, thereby facilitating the formation of opposition coalitions. In other words, it shows the long-term moderating process of mass protests in Malaysia and the development of coordinated negotiations between the main opposition parties, the Democratic Action Party (DAP) and the Parti Islam Se-Malaysia (Malaysian Islamic Party: PAS), which contributed to 
the formation of the opposition coalition that led to regime change. The analysis implies that repeated elections can deter regime change caused by challenges outside the political institutions, making regime change more likely to occur within the institutions.

\section{Figure 1: Authoritarian Regime Survival Duration and The Number of Repeated}

\section{Elections. $^{3}$}

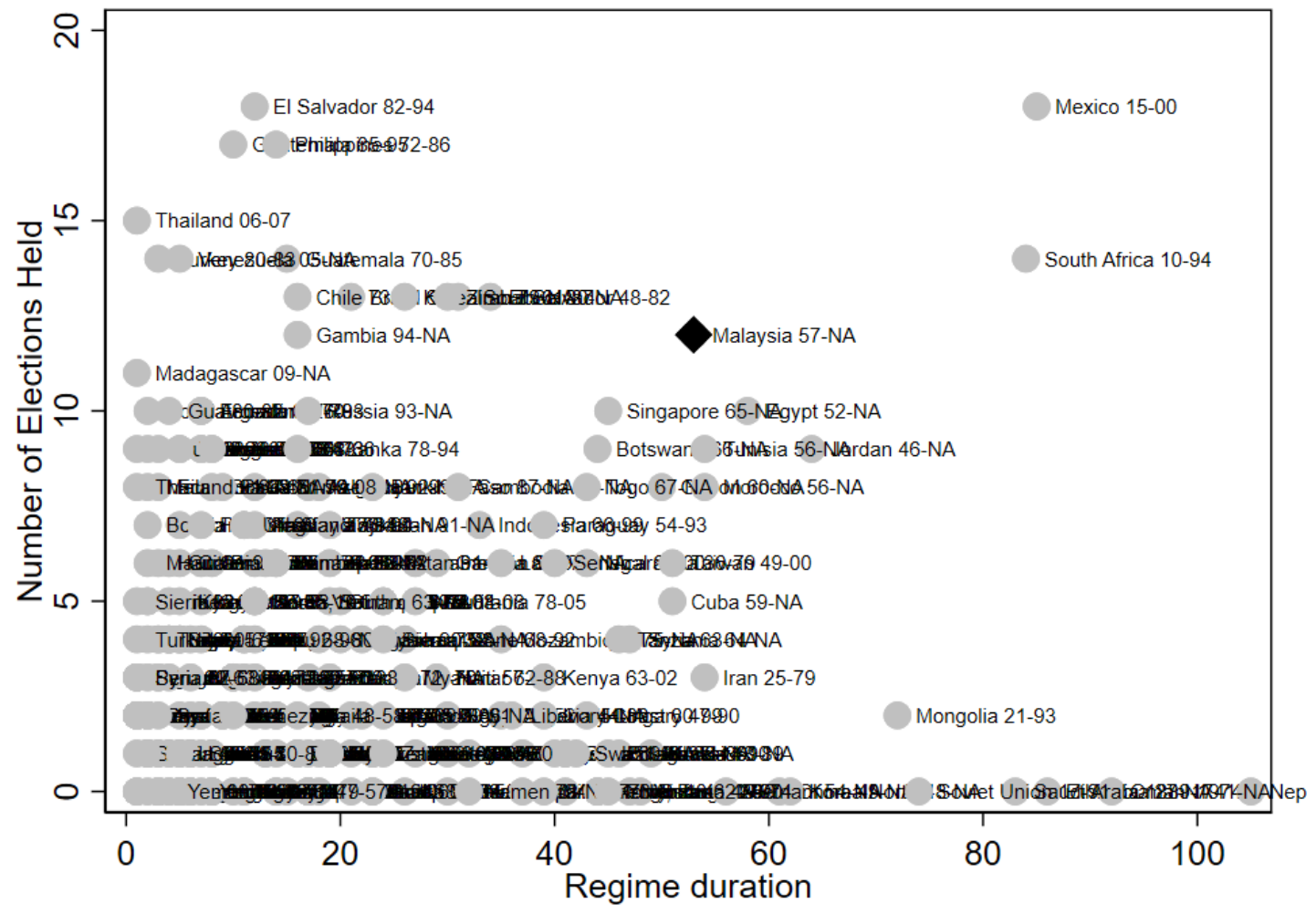

In order to capture the mechanism of transforming the oppositions' challenge by repeated elections through case-study analysis, it is necessary to deal with a case where the strategic options have had time to change, that is, a specific duration of regime survival and the conduct of repeated elections. Malaysia, which this paper deals with, is a typical example. Figure 1 plots the years of the regime survival and the number of elections held (up to that point in the case of regime change) for authoritarian regimes 
between 1948 and 2008. Malaysia had been in existence for 53 years and had held 12 elections by 2008, so it was undoubtedly a long-survived regime and accumulated much electoral experience. It is a good case for uncovering the mechanisms of repeated elections, as observed a definite shift in the opposition challenge, including the consequence that the opposition coalition defeated the ruling $\mathrm{BN}$ for the first time in the 14th general election in May 2018.

By focusing on the oppositions' challenge, this paper contributes to identifying the mechanisms by which the effects of repeated elections affect the stability of authoritarian regimes. As discussed below, the debate on repeated elections has focused on either the regime stability effect as one of the dictator's survival strategy or the democracy-promoting effect of political and social liberalization. The contrast between the two debates stems from the different actors assumed within the mechanism. By focusing on the strategies of oppositions affected by both mechanisms, this paper shows that the two arguments capture different aspects of the repetition effect of elections and are coextensive. Applying the mechanisms presented in this paper to Malaysia's case will provide a more in-depth understanding that the post-1998 rise of street demonstrations in civil society and collaboration with the opposition parties in Malaysia have emerged with an essential basis in the earlier opposition challenge experiences. Moreover, the analysis suggests there is a route that competitive authoritarian regimes that have been stable for a long time proceed to democratization through elections that have been the source of that stability paradoxically.

The paper is structured as follows. The next section summarizes previous research on elections and oppositions in authoritarian regimes and Malaysia. The third section presents a theoretical framework for the impact of repeated elections in 
authoritarian regimes on opposition's strategic options. The fourth section is a historical case study of oppositions in Malaysia and builds on the previous section's framework to examine the transformations regarding mass protests and opposition coalitions. The fifth section examines alternative explanations of the paper's questions that could be assumed from previous studies of Malaysian politics and describes the framework's validity. The final section summarizes the discussion and challenges.

\section{Past Literature on Repeated Elections and Opposition challenges under}

\section{Authoritarianism}

As for the effects of elections in authoritarian regimes, while there is some agreement on the argument that electoral fraud or the event of conducting elections itself contributes to the weakening of the regime as a focal point for mass mobilization, ${ }^{4}$ there has been some debate about the effect of repeated elections, which is the interest of this paper.

Studies arguing that dictators use elections to maintain the regime by cooptation of threatening internal elites and masses have revealed that elections function to distribute resources, gather information on the distribution of support for the ruling and opposition parties, and publicly show the regime strength displaying the electoral results. ${ }^{5}$ This function also played an essential role in maintaining BN's regime in Malaysia, as the source of BN's strength, the three M - Money, Machine, and Media. ${ }^{6}$ In addition to punishing/rewarding state governments through financial expenditures, ${ }^{7}$ resources such as ministerial posts and constituency allocations strategically distributed and used to maintain the regime. ${ }^{8}$ Moreover, there has been a vast amount of research on how organized networks in villages acted as machines to collect votes for the $\mathrm{BN},{ }^{9}$ and how much the $\mathrm{BN}$ dominated in all aspects of media, including constrained reporting 
opportunities by mainstream media and restrictions on publications. ${ }^{10}$ It has also been argued that the discourse of developmentalism, which evaluates economic growth and improved living standards under the BN regime, spread to the masses in the $1990 \mathrm{~s}$, especially among the middle class, leading to a widespread political attitude of restraint in criticizing the BN. ${ }^{11}$

On the other hand, there is a large body of research showing that repeated elections promote political and social liberalization and contribute to democratization through a practice of democracy. ${ }^{12}$ This discussion has a high affinity with the discussion of the 1998 Reformasi movement and its consequences in Malaysia. Weiss argues that focusing on civil society and opposition parties as opposition actors both within and outside the institutions, civil society actors have led the political culture and norms in Malaysia to change from ethnic politics to a non-communal direction and to work with the opposition. ${ }^{13}$ She points to the importance of the political system's nature, as such a change was possible because it opened up a certain degree of political opportunity for oppositions and allowed room for mass mobilization and organization. ${ }^{14}$ The opposition groups engaged in political participation within the institution rather than through protests because it was possible to try political reforms through institutional politics and be less likely to be repressed than extra-institutional action. ${ }^{15}$ She and others argue that this specific degree of opening up of political opportunities led to the consequences of the 1998 protests in Malaysia and Indonesia and the difference between regime maintenance or democratization. ${ }^{16}$

Some scholars suggest that holding elections destabilizes the regime when first introduced elections, but contributes to stability after several elections, bridging two competing claims about the effects of such repeated elections. ${ }^{17}$ However, all of them 
focus on the dictator's regime maintenance strategy or the liberalization of civil society and political competition, so the opposition's changing strategic options are outside the scope of the analysis. The former study focuses on the effect of uncertainty reduction in elections and the latter on the self-enforcing effect of the regime on the rules of democracy, respectively. ${ }^{18}$ In the effect of reducing uncertainty, resource distribution, in particular, can strengthen patron-client relationships efficiently as the regime repeatedly uses electoral opportunities to distribute resources to the masses, contributing to the marginalization of oppositions. ${ }^{19}$ The regime's self-enforcing effect also imparts to the regimes the legitimacy of having a monopoly on power because they hold regular elections and have the support of the masses. ${ }^{20}$ In other words, only one aspect of each effect on the opposition's challenge is assumed in the mechanism in these discussions. Therefore, to capture the overall picture of opposition challenges in authoritarian regimes, it is necessary to consider the impact of these two effects. While Weiss and others' points about the opening up of political opportunities and the nature of the political system in Malaysia is an essential factor to consider when comparing it with cases such as Indonesia, the subsequent rise in protests in the 2000 s and the fact that challenge through political institutions, rather than direct regime overthrow, was still prioritized, requires additional explanation. Even when the political system is less violent and more competitive, two situations can arise one in which institutional politics absorbed popular discontent and deter protest outbreaks, and the other in which discontent grows to such an extent that protests grow to a large scale, even though they do not lead to direct overthrow actions. Furthermore, if the regime is not highly violent in the latter situation, even more so, why don't the oppositions use the protests as a means to overthrow the regime. In order to explain it, it is necessary to look at the mechanisms by which political institutions 
influence oppositions' challenge. Other studies on the challenge of oppositions to authoritarian regimes include Lust-Okar's work focusing on differences in competing structures within oppositions, ${ }^{21}$ an examination of mobilization mechanisms using detailed data on participants in recent protests, ${ }^{22}$ and studies on the effectiveness of

opposition coalitions and democracy promotion. ${ }^{23}$ Among them, Gandhi and Reuter ${ }^{24}$ show the effect of the opposition's experience of electoral participation on the formation of opposition coalitions, and Sato and Wahman ${ }^{25}$ show that the interaction of protests and opposition coordination promotes democratization. While each of these studies partially supports the mechanism in the argument that repeated elections change opposition challenges, there is room for this paper's contribution in that they do not include both within/extra-institutional challenges and changes in oppositions' strategies in the scope of their analysis.

\section{Theoretical Explanation}

Next, this section considers the mechanisms by which repeated elections influence opposition challenges and provides a theoretical framework. The regime assumed here is the so-called electoral authoritarian or competitive authoritarian regime, ${ }^{26}$ which holds elections with a multi-party system. Briefly, the two effects produced by repeated elections, the aforementioned uncertainty-reducing effect and the self-enforcing effect on the rules of democracy, provide a stabilizing factor for the regime and influence the opposition's strategy of challenge (Figure 2). That stems from the fact that it is essential for oppositions to pay attention to, gain support, and mobilize the masses, whether they use either protest or elections to achieve the goal of overthrowing the incumbent regime. ${ }^{27}$ 


\section{Figure 2: Causal Mechanism of Repeated Elections Affecting Opposition Challenges}

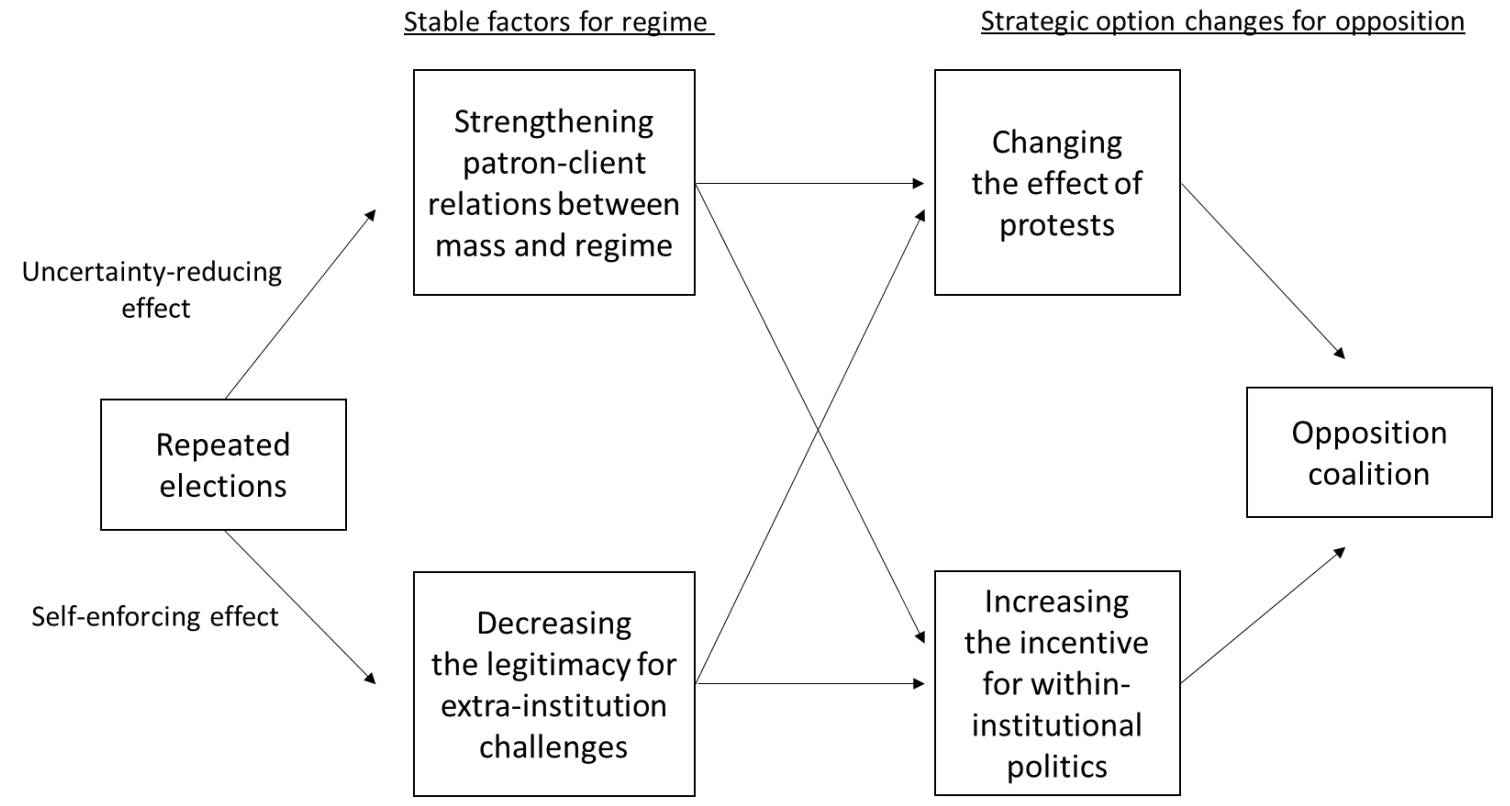

First, in the early stages of the introduction of elections, protests that mobilize the masses will likely be an effective way for oppositions to challenge the regime. The uncertainty-reducing effect of repetition, as previous studies have pointed out, is that while the regime can effectively strengthen its patron-client relationship with the masses through the distribution of resources, oppositions find it more difficult to mobilize the masses to protest for the overthrow of the regime as elections repeat. Repeated elections reduce the benefits of the masses' participation in overthrowing the regime by supporting the opposition groups. Because the masses have experienced resource allocation from the regime in past elections, they are aware of the benefits of supporting the ruling party in elections. Repetition allows the masses to trust the resource allocation in future elections, thus increasing their certainty about future gains. Therefore, participation in protests to directly challenge the regime has the potential to diminish future gains and also risks repression, making participation less of a beneficial option for the masses.

Moreover, the self-enforcing effect on the rules of democracy gives the regime 
the legitimacy to monopolize power based on popular support in elections. Therefore, in the absence of apparent moral hazard by the regime, such as blatant rigging of election results or suspension of implementation, it is difficult for oppositions to solve the coordination problem and mobilize the masses to massive protests as to gain legitimacy seizing power.

If repeated elections discourage oppositions from overthrowing the regime from outside the institutions, they are likely to facilitate challenges within the institutions. The uncertainty-reducing and self-enforcing effects of repeated elections also work against within-institutional challenges by oppositions.

The self-enforcing effect through repetition inextricably links to the rules of political competition, where if the incumbent regime loses an election, it relinquishes power following the result. Moreover, as long as the regime is self-enforcing, oppositions are forced to within-institutional challenge against the regime based on the rules of democracy if they want to do with public support. In a situation where overthrowing the regime outside the institutions and reversing the imbalance of power and resources that exists between the ruling party and the oppositions has become difficult, the next best option is to participate in within-institutional politics, if their opportunities are open, to increase the number of seats won and expand political influence.

The uncertainty-reducing effect strengthens the learning process of opposition parties through the accumulation of electoral participation experiences, contributing to their strategic nature. Repeated and regular elections enhance the strategic nature of both incumbents and challengers (opposition politicians). ${ }^{28}$ When opposition parties seek to increase the number of seats won in elections, an effective strategy is to coordinate and form coalitions with other opposition parties with different preferences across the 
cleavages, even if it means compromising their policy preferences. In authoritarian regimes, opposition parties have a limited support base and limited ability to gain seats on their own because they are "divided" according to ethnic and ideological cleavages to prevent oppositions from uniting to challenge the regime (Lust-Okar 2005). The experience of electoral participation will provide the opposition with information about the current or potential support base of its party and other parties. As the accuracy of the information will increase through repetition, they will recognize and learn the limits of their ability.

However, it is not easy to build cooperation among the opposition parties, as coordination problems can arise due to existing cleavages, differences in the acceptance of co-optation by the regime, inter-party negotiations, and the cost of mediation to opponents of cooperation within the parties. The key to solving them is the occurrence of mass protests. If protests have lost their legitimacy as a means of overthrowing the regime after repeated elections, as mentioned above, even if they do occur, they do not pose a direct threat to the regime's stability and function as an expression of dissatisfaction of some masses and oppositions. That is also consistent with the findings that, by the interaction between the political participation outside and within the institutions, the political institutionalization and competitiveness discourage mass participation in protests and encourages voting participation. ${ }^{29}$ Some research shows that even under authoritarian regimes, the regime allows protests to some extent and uses them to gather information and vent mass discontent. ${ }^{30}$ In other words, the occurrence of protests in situations where the regime has stabilized indicates the need for strengthened co-optation and careful control to prevent discontent from spreading, but the regime does not need to repress thoroughly, given the risk of backlash from the mass. 
However, for the opposition parties, even if it is not a protest aimed at the direct overthrow of the regime, it has an essential function as a signal of the likelihood of the ruling party supporters' defections and the size of the potential swing vote for the opposition. Such protests may arise from the masses, or they may be led by opposition parties or other dissident groups to arouse popular discontent against the ruling party. ${ }^{31}$ If mass protests grow, there is a higher expectation of an increase in the number of seats for opposition parties when they form a coalition, even at the cost of intra-party coordination and policy-oriented compromise than when they split votes of the government disapproval. Thus, through repeated elections, as experienced opposition parties recognize the need for coordination, the incidence of protests becomes a means for the masses to show their dissatisfaction with the regime and promote cooperation between opposition parties within the institutions.

This section developed a theoretical framework in which repeated elections in authoritarian regimes reduce the regime's instability due to opposition protests while promoting inter-oppositional coordination as within-institutional challenges. The next section illustrates its logic by examining the case of opposition challenges, i.e., mass protests and opposition coalitions in Malaysia.

\section{Case Study: Opposition Challenges in Malaysia}

This section drawing on the framework described in the previous section shows the changing impact of the protests on regime stability in Malaysia, the increased influence of the protests on within-institutional politics, and the development of inter-opposition coordination and coalition formation. The analysis divides the period into four sections 
for each of Malaysia's past major protests and observes these changes and the oppositional negotiations in the elections that took place during the same period. Specifically, those are (1) the post-independence period to 1969 (the May 13 incident), (2) 1970-1990 (protests making demands on individual issues such as class and ethnicity), (3) 1998-2004 (the Reformasi movement), and (4) 2005-2018 (the Bersih movement). In order to focus on the actual protests and their impact on the election, the analysis will exclude the period 1991-98 because the mass crackdown on oppositions in 1987, discussed below, led to quiescence in protests and civil society organizations' activities.

\section{-Moderation of Mass Protests}

First, to show the changing impact of mass protests on regime stability, the analysis will identify the long-term moderation of mass protests in Malaysia. It will examine (1) the role of mass protests outside the institutions among opposition groups in each period, and (2) the degree of the mass protest moderation that occurred, respectively. In particular, the latter point, the moderating of protests, will be judged by whether they did not seek towards two criteria: (a) direct challenge to the regime through protests, and (b) demands related to ethnic issues. These two criteria are the excuses that the regime always raised in justifying the suppression of protests in Malaysia. (a) Direct challenges through protests got suppressed to maintain security and order, and (b) protests related to ethnic issues were repressed as actions that "disrupted inter-ethnic relations" in the name of ensuring that ethnic clashes such as the May 13 incident, noted below, would never be repeated.

In Malaysia from independence until 1969, (1) the legitimacy of institutional 
politics and the electoral system was not recognized even by the opposition parties participating in elections. Additionally, (2) mass protests easily triggered inter-ethnic clashes and escalated into riots, posing a tremendous threat of social unrest, security disorder, and regime instability to the extent that the regime became increasingly authoritarian.

First, the opposition group that sought to overthrow the regime by force was the Communist Party of Malaya (CPM), which had been active in guerrilla activities since before independence. However, after a state of emergency was declared in 1948 during the British colonial period, the CPM got thoroughly suppressed. In other words, the most radical oppositions were already not allowed to challenge the regime around the independence period in Malaysia.

Moreover, even in the opposition parties, elections were not perceived as a more useful or rational means of challenging the regime than any other means outside the institutions. Though the Malayan Labour Party was the second most powerful opposition party in the 1959 general elections, it decided to abandon parliamentary democracy and adopt an extra-parliamentary struggle to educate and mobilize the masses directly since 1964. ${ }^{32}$ They led protests in Penang in 1967 against the currency devaluation, which reached riots, and they also boycotted their participation in the 1969 general elections and obstructed the masses from voting. ${ }^{33}$ While the policy shift to extra-parliamentary struggle got influenced by internal power struggles and the Cultural Revolution in China as external factors, ${ }^{34}$ the critical point is that even the leading opposition parties that won seats in the elections prioritized the option of seeking to overthrow the regime through popular uprisings over political participation within the institution. Moreover, even the Chinese-base opposition DAP, which was the most bitterly opposed to the Labour Party 
among the opposition parties and denounced the CPM's armed struggle and the proCommunism of the Labour Party, argued that their actions were due to disappointment with government policies and political systems and that the government was responsible for their actions. ${ }^{35}$

The ethnic clashes that erupted immediately after the 1969 general election represented a significant threat to the regime's stability as the protests spread to the masses along with the chaos. Street marches by supporters of both sides, which took place after the Chinese opposition parties' rise and the ruling party's retreat in the election, confused and led to riots that engulfed the masses. The riots, known as the May 13 Incident, were a disruption of the security order that threatened the regime's stability and exacerbated inter-ethnic relations between Malays and non-Malays (Chinese and Indian). Subsequently, it became a reference point for the repression of protests and an opportunity for the regime to become more authoritarian.

In the 1970s and 1980s, (1) opposition actors who challenged the regime outside institutions with aims to overthrow the regime were virtually absent, and opposition parties, civil society organizations, and students carried out and supported mass protests in order to achieve class and ethnic claims, and political reforms. (2) However, claims and protests on ethnic issues were perceived by the regime as a threat to their stability, and the Chinese language education movement in the late 1980s caused so much ethnic tension that the government, fearing a repeat of the 1969 riots, staged massive repression of all opposition actors.

Lim Kit Siang, a member of Parliament affiliated with the DAP, said, "(And) we will continue to draw attention to the Government to the possibilities of revolution unless the basic political, social, economic and cultural grievances of the people are attended 
to." ${ }^{36}$ As he said, the DAP actively intervened and supported labor disputes, protests against local development projects, and squatters during the 1970s and 1980s. ${ }^{37}$ Similarly, student organizations and the Muslim conservative opposition party PAS have also supported mass protests, for example, leading the 1974 squatters in Johor and the mass demonstrations by rubber and paddy smallholders in Kedah, 1974 and 1980. In these mass protests, the police selectively arrested and repressed only the opposition politicians and leading activists involved, rather than the participants as a whole. For example, the government had a distinctly different response to the masses and opposition actors in the protests, as in the 1980 demonstrations in Kedah, where the government decided to provide cash subsidies immediately upon the farmers' demands.

Among oppositions, there were also political actions outside the institutions to demand that the government change its policies. At the center of this movement were the advocacy-type NGOs that emerged after the 1980s. These organizations advocated for specific issues such as human rights, political reform, environmental issues, and consumer issues, educated the public, and campaigned against the enactment of legislation. The government often accused them of being "minority pressure groups." The then Prime Minister Mahathir claimed that NGOs' criticism and political actions were the disruptive challenges to the legitimate authorities and they would inevitably resort to violence and terrorism to achieve their objectives. ${ }^{38}$

Under these circumstances, the Chinese language education movement heated up in 1987. Internal splits within the UMNO led to an inability to control the party, and UMNO youth groups opposed to the movement held massive counter-rallies, which led to increased ethnic tensions and fears of a recurrence of the 1969 riots spread to the masses. ${ }^{39}$ That led to the government's mass crackdown (Operasi Lalang) under the 
Internal Security Act (ISA). ${ }^{40}$ The targets of these arrests included not only the Chinese ruling and opposition parties and socio-economic groups involved in the movement, but also all the actors who were critical of the then-Prime Minister Mahathir and the BN regime, including some members of the UMNO, the opposition PAS, other NGOs, and the media. In other words, while the protests by the oppositions at the time did not intend to overthrow the regime, they were perceived by the regime as a threat to social security and even the regime stability in that they raised demands related to ethnic issues.

The Reformasi movement in 1998 triggered an upsurge in mass protests that had calmed down after Operasi Lalang. (1) Initially, the movement led by Anwar Ibrahim, who got dismissed as then-deputy prime minister, aimed to demand the resignation of then-Prime Minister Mahathir. However, (2) because it adopted a non-violent strategy to avoid disturbing social unrest and order, and its demands did not relate to ethnic issues, it led to solidarity among opposition parties, civil society groups, and other oppositions and expanded from young Malays to the non-Malay urban middle class, resulting in a large scale.

After Anwar was ousted from UMNO in 1998 due to a conflict with Mahathir, he launched the movement demanding political and economic reforms and the resignation of the prime minister and held a rally in Kuala Lumpur which tens of thousands of supporters gathered. Although Anwar got arrested under the ISA, the organizers' arrest did not stop it, unlike past protests. The rallies continued to spill over to other than the original Anwar supporters.

However, because the protests did not aim to overthrow the regime directly and did not raise any demands related to ethnic issues, it did not lead to an unstable social situation that could grow into a riot as in the past. First, the activist side voluntarily took 
a non-violent stance and attempted to curb violence and disruption among the participants. The rallies only expressed dissatisfaction with the prime minister and called for his voluntary resignation, and were not intended to pull him out of his position directly. At the first rally in September, Anwar himself asked participants to "orderly dissolve (bersurai secara teratur)" although there were eventually a few clashes with the police. ${ }^{41}$ The DAP and the movement support group also called for restraint and non-violence from the participants to avoid the disruption. ${ }^{42}$

Secondly, although it was not the intended direction, the Reformasi movement was not a protest aimed at realizing an ethnic claim. The fortuitous composition of the participants, with the mobilization of his supporters, young and middle-class Malays, in the wake of Anwar's expulsion from UMNO, did not cause an ethnic tension. Moreover, the spreading of Anwar's photos showing him beaten during police interrogation led to increased criticism of the government on human rights issues, including arrests by the ISA and repression of demonstrations. In addition to political reform that Anwar called for, those issues were common across ethnic lines and thus increased criticism of the BN among oppositions like opposition parties, civil society NGOs, and the individuals of the non-Malay urban middle class.

Hence, the protests did not guide the unstable social situation, nor did it lead to thorough repression by the government. Although the government arrested hundreds of rally participants, it was not until 2000 after the general election that they began to intervene seriously in the movement, with some opposition politicians and activists arrested and prosecuted (and released immediately) under the Sedition Act and other laws rather than the ISA.

Since the Reformasi in 1998, there has been an increase in street protests by civil 
society organizations in Malaysia. Among them, the Bersih movement, which began around 2005 and aimed to reform the electoral system, mobilized an unprecedented number of masses into the streets. As noted above, the 2015 demonstration (Bersih 4) drew up to 250,000 people. It (1) aimed to increase support for the opposition and influence the elections through protests. Its stance was strongly influenced by (2) the fact that opposition politicians and civil activists formed it as a non-ethnic and non-violent means of protest, based on the experience of the Reformasi. Non-ethnic claims enabled solidarity between opposition politicians, and non-violent means enabled them to expand mass mobilization.

The Bersih movement's organizers perceived the protests not as a direct challenge to the regime, but as a means of influencing the elections. Hishammudin Rais, one of the executives, said in an interview that he believed that "a mass protest will translate anger into votes." ${ }^{\prime 3}$ When opposition politicians and civil activists organized the Bersih, there was a widespread perception within them that there was an electoral legitimacy, that is, that the regime change should occur through elections with mass support. They thought that mass protests would encourage the masses to vote for the opposition by making them aware that there were many similarly discontented people with the BN.

The Bersih was also a clear inheritor of the Reformasi's two tactics of a nonviolent and non-ethnic political reform movement. As discussed below, the Bersih began as a stepping stone to cooperation between opposition parties and thus became a movement focused on electoral reform that did not rely on ethnic claims. Opposition politicians who became early Bersih leaders after their defeat in the 2004 general election shared the recognition that the problem of electoral fraud needed to fix for the future 
struggles. ${ }^{44}$ After the coalition's collapse in 2001, as explained next, the politicians from PAS and DAP seeking cooperation between them organized the Bersih based on the idea that both parties could cooperate on electoral reform, which was not an ethnic issue, but a single issue. Though the movement became non-partisan and refused interference from political parties after relaunching as Bersih 2.0 in 2010, many opposition politicians participated in rallies and gave speeches. Thus, the Bersih 2.0 continued in the same direction of electoral regime change.

The non-violence strategy in the Bersih was also crucial in growing the scale of mass mobilization. Previously, street protests were feared by the masses as a reminder of the May 13 riots. The Bersih tried various framing efforts to dispel such fears, including wearing yellow T-shirts, the symbolic color of the movement, and social media promotion. Marina Mahathir, who participated in the 2011 Bersih 2 rally, stated that the demonstration had a "carnival" atmosphere, and the people and police were no different from a typical Saturday. ${ }^{45}$ Hishammudin Rais also said that after this 2011 rally, people were no longer afraid of street protests, which became part of the political process. ${ }^{46}$ The number of participants afterward snowballed, but clashes with the police ceased to occur, and it was all about peaceful rallies. Based on this mastery of protests by both the organizers and the police in the Bersih rallies, Iga argues that Malaysia reached a point where "street protests become a daily routine." 47

As discussed here, on the other side of the BN regime's consolidation through repeated elections, mass protests in Malaysia moderated as they avoided the two main threats to regime stability: the direct overthrow of the regime and the pursuit of ethnic issues. Furthermore, crossing the barriers to mass mobilization in Malaysia, namely violence and ethnic cleavages, led to the growing participants of protests. 


\section{-The Pursuits for Opposition Coalition and the Promotion Effect of Mass Protests}

Following the same time-division as in the previous section, this section observes the historical changes in inter-opposition coordination in the general elections around the onset of the protests, showing that opposition parties repeatedly tried it and moderated protests were an essential facilitator of coalition formation. The focus here is on the coordinated negotiations between the Muslim conservative party PAS and the DAP, a multi-ethnic, social democratic-oriented party with a Chinese support base. The two parties competed with the $\mathrm{BN}$ as the main opposition parties in Malaysia for years. However, while PAS held the party discipline of building an Islamic state, the DAP denied preferences for Malays and oriented towards the equality of all ethnic groups. These different policies were always an obstacle in the quest for inter-party cooperation. The $\mathrm{BN}$ used this rift precisely to prevent and divide their coordination and to stabilize the regime.

Nevertheless, cooperation attempted for many years, because the electoral competition around ethnic issue favors the $\mathrm{BN}$, a centrist, cross-ethnic coalition government and the two parties realized that unless they fought together, it would be difficult to win a majority on their own. It was necessary to compromise their conflicting claims for forming a coalition. The keys to overcoming the obstacles were electoral experience and mass protests.

BN's moderate policy on ethnic issues intended to stabilize popular support through the vote-pooling effect among different ethnic groups. ${ }^{48}$ According to Nakamura, the BN gained seats in many ethnic-mixed constituencies where they put up a united candidate because, with moderate policies, Malay voters voted for non-Malay candidates 
(vice versa), emerging the exchange of votes between different ethnic groups. ${ }^{49}$ What is important here is that the absence of the opposition coordination caused the competition between the same ethnic ruling and opposition party in ethnic-mixed constituencies, ensuring the vote-pooling effect for the $\mathrm{BN}$. In other words, the inter-opposition coordination had the potential to threaten the BN's votes.

Then-Prime Minister Rahman and other BN executives recognized the votepooling effect from the beginning of the coalition government and allocated candidates for maximizing it, ${ }^{50}$ but the opposition parties were also aware of this effect. In the opposition, the biggest issue was cooperation among the many Chinese opposition parties until 1969, including the Labour Party of Malaya mentioned earlier. However, in the 1969 general elections, there was an attempt at underwater coordination between the PAS and the DAP. According to Rahman's statement, the DAP and PAS had a close relationship, with the PAP in Singapore funding the PAS to facilitate candidate fielding through the DAP to overthrow the regime. ${ }^{51}$ In non-Malay-majority constituencies, the PAS, in addition to the ruling MCA and the opposition DAP, put up candidates and attempted to funnel the Malay vote that would have gone to the MCA through the vote-pooling effect to the PAS. ${ }^{52}$ Rahman condemned the PAS as the greatest treachery against the Malays. ${ }^{53}$ Though there was a limited effect of such the three-cornered battle on the election result, ${ }^{54}$ the existence of the attempt shows that the opposition had already been aware since the 1960s that cooperation between the left and right opposition parties could destroy the BN's support base.

It was in the 1980s that negotiations between the DAP and PAS again surfaced. After the suspension of Parliament due to the May 13 incident, many Chinese opposition parties joined the $\mathrm{BN}$, the DAP remaining the only prominent Chinese opposition party 
that could retain its seats. On the other hand, the PAS briefly joined the BN but got expelled from it at the end of 1977. Although the idea of a coalition between the two parties emerged at each election in the 1980s, it became clear that compromise would still be challenging to achieve over the PAS's party principle for building an Islamic state. There was also a gap in the timing of the two parties' motivation to form a coalition. However, in the 1990 general election, while the conflict over party principles continued, a pseudo-cooperation arose based on the experience of trial and error, with the new party born from the split in the UMNO acting as a mediator.

The PAS, which had left the BN, and the DAP leaders already came up with the idea of forming a coalition to expand the opposition forces, but the party could not unite against the leaders' desire. In early 1981, Asri Muda, who was president of the PAS, mentioned the possibility of an electoral cooperation agreement between the two parties. He proposed that the PAS and the DAP first and foremost adjust the candidates in order to split the vote, as did in ' 69 , to have the $\mathrm{BN}$ win less than two-thirds majority of the seats in Parliament, a requirement for constitutional amendments, instead of aiming to form a coalition government beyond their ideological differences. ${ }^{55}$ Some members supported the idea, partly because of the perception that a split in the opposition led to the BN's victory, but there was a massive backlash in the party's majority, and he quickly withdrew it. ${ }^{56}$ In the DAP, General-Secretary Lim Kit Siang continued to be keen on the coalition and called for its formation, but this did not succeed in the 1982 general election. ${ }^{57}$

On the non-Malay side, Chinese socioeconomic organizations also began to call for the formation of an opposition coalition led by PAS and DAP as a counter to the BN, because they understood the need to influence on politics through political parties after 
the rise of the Chinese language education movement from the late 1970s onwards. Fifteen organizations, including educational groups, local chamber of commerce and industry, and local Chinese Assembly Hall, began negotiations with PAS in September 1985 to strengthen their lobbying of political parties, and in January 1986 established the National Chinese Civil Rights Committee (CRC) as an organization to facilitate the coalition formation. ${ }^{58}$ DAP executives also showed a desire for electoral cooperation with PAS from late 1985, leading to the first formal negotiations between them, which had not occurred in the last general election in 1982. However, negotiations continued until July, just before the dissolution of Parliament, but the negotiations broke down when the DAP decided not to join the coalition unless the PAS withdrew its two prerequisites of building an Islamic state and the Muslim leadership of the coalition ${ }^{59}$.

In other words, once the actual negotiation process began, this experience revealed that, as had expected, it was impossible to compromise on each other's party principles. Kua Kia Soong, one of the CRC leaders, said that the parties should have discussed what they could agree on rather than their differences, which was futile to discuss the pros and cons of the PAS's goal of establishing an Islamic state. Neither party was at a stage where reasonable compromises could be made, with coalition formation being the top priority.

In the next general elections in 1990, Parti Melayu Semangat 46 (Spirit of 46 Malay Party: S46), formed by former Finance Minister Razaleigh Hamzah, who had left UMNO, and the DAP and PAS formed a coalition (Gagasan Rakyat and APU), respectively, leading to the formation of a de facto opposition coalition with S46 acting as the mediator. The PAS and DAP did not form a unitary coalition due to differences in the party lines, but the two coalitions did end up launching a joint manifesto. ${ }^{60}$ Although 
they failed to prevent $\mathrm{BN}$ from winning a majority, the APU dominated the seats in the Kelantan Legislative Assembly, and the formation of the opposition coalition had some success. Nevertheless, before the next general election in 1995, S46's weakening and returning to Malay nationalism led to a breakdown in the coalition with the DAP.

That is an example of how a split in the UMNO can promote the formation of an opposition coalition, as will be discussed below, but compared to the case of the 1998 Refomasi and the subseqent election, it should be considered that the split was not enough to create an actual coalition although it was significant. Furthermore, the Chinese education movement in 1987 and the following mass arrests were signs of growing discontent with the $\mathrm{BN}$ among Chinese or non-Malay voters, but unlike the Reformasi movement in 1998, they did not lead both PAS and DAP to expect BN's supporters to swing. In other words, the expectation of the supporters' defection, rather than the existence of a split in the UMNO, was the coalition formation's driving force.

The first opportunity for PAS and DAP to form a united opposition coalition came in the general elections the year after the Reformasi movement in 1998. The discontent of the young and middle-class Malays with the $\mathrm{BN}$, as demonstrated by the Reformasi, was perceived as an unprecedented opportunity to shake the BN's strong support base. The two parties thus agreed to form a coalition. That can be seen as an evident moderating in that the two parties worked together for the first time while retaining and maintaining each other's opposing party principles to counter the $\mathrm{BN}$. This difference in the party principles eventually attributed to the coalition's demise. However, the experience of forming this coalition increased the number of members on both sides who were keenly aware of the need to form a coalition against the $\mathrm{BN}$ and contributed to the subsequent coalition forming. 
Shortly after Anwar's arrest in 1998, both PAS and DAP worked with NGOs to establish their organizations in support of the Reformasi. The groundwork for their cooperation thus arose even before the negotiation of coalition formation. Anwar's wife Wan Azizah established Parti Keadilan Nasional (National Justice Party: PKN. After 2003, renamed Parti Keadilan Rakyat [People's Justice Party: PKR]) in early April 1999, followed by PKN, PAS, DAP, and other party forming the Barisan Alternatif(BA) at the end of April.

The DAP argued in its organ that the 1999 general election was a "historic opportunity" that could break the BN's two-thirds majority, and they must seize it. ${ }^{61}$ It also stated that both DAP and PAS had decided to come out of their "cocoons" and work together for justice, freedom, democracy, and good governance for all Malaysians and must respect each other's different positions, which was a longstanding challenge. ${ }^{62}$ In other words, only in the face of the "historic opportunity" of the young and middle-class Malays to criticize the $\mathrm{BN}$ did they succeed in suspending their respective positions and prioritizing cooperation.

The 1999 general election results showed that PAS more than tripled its seats from the previous one, took state government in two states, and Malay defections were evident, while $\mathrm{BN}$ maintained more than two-thirds of all seats and non-Malays, especially the Chinese BN supporters, did not shift. Except for the young and urban middle class, who are sensitive to human rights issues, non-Malays tended to see the Reformasi as a power struggle within the UMNO or Malays. Moreover, the early recovery from the Asian economic crisis and fewer defectors from UMNO further inhibited the movement's spread. ${ }^{63}$ The first cross-ethnic opposition coalition achieved some results, but as the election ended and the influence of the Reformasi waned, the DAP clashed with 
the PAS, which reverted to the Islamist line, and left the BA.

However, the experience of the BA helped in the seeking of cooperation after the 2004 general elections. A growing number of people between the two parties perceived the formation of an opposition coalition as an effective way to counter the BN. They organized a movement for electoral reform in 2005 as a stepping stone to the inter-party coordination, mobilizing the masses into street protests, as mentioned above. The opposition parties' success in the 2008 general elections, the reunification of the coalition, and the maintenance of power in the 2013 general elections led to a shared understanding of coalition-building effectiveness. As a result, when the confrontation between PAS and DAP broke out again in 2015, the coalition did not merely end with the dissolution, but rather the cooperation-oriented members left PAS and quickly re-formed a new coalition with DAP and PKR. It means that the countermeasure of forming a coalition became the default for the opposition parties.

As mentioned earlier, the Bersih movement began as a form of coordination between opposition parties outside political institutions, including civil society NGOs. After the DAP's exit from BA in 2001, there were many members in both the DAP and PAS who opposed the cooperation due to the difficulty of coordinating candidates and being an "unnatural" coalition with fundamentally opposing party principles. Especially within the DAP, some members sharply criticized the coalition with PAS because some executives failed to win the 1999 general election. ${ }^{64}$ Such internal criticism made it challenging to form a coalition in the event of the 2008 general election. Therefore, those in PKR, DAP, and PAS who were aware of the necessity of opposition coordination organized Bersih in 2005 as a foothold.

The decline in support for BN, especially among non-Malays, in the 2008 
general elections was due not only to the Bersih rallies, but also to the increase in other mass protests by the Malaysian Bar Association and Hindu rights groups in 2007, the widespread use of the Internet, and increasing urbanization. An unexpected opposition breakthrough, also known as a "political tsunami," occurred, with BN's seats falling below a two-thirds majority in Parliament for the first time. ${ }^{65}$ Although the opposition did not reach a formal coalition before the election, DAP and PAS agreed to coordinate their candidates, with PKR as a mediator, to unify their candidates in each constituency. After about three weeks of negotiations from the polling day, the three parties formed the Pakatan Rakyat (People's Alliance: PR). The ties between civil society and the opposition further strengthened as the activists who had played a core role in Bersih won seats from various opposition parties.

In the 2013 general election, the Bersih rallies grew in size, as described above, and public expectations of regime change were higher than ever before, with the PR gaining a larger share of the vote than the $\mathrm{BN}$, but the $\mathrm{BN}$ retained its majority of seats. The decisive factor in the collapse of PR in 2015 was again the conflict between PAS and the DAP over religious issues, that is, the introduction of the hudud law. ${ }^{66}$

However, the issue also led to conflict within PAS, leading to a split in the party. In June, PAS's intention to leave the coalition was approved by PKR and DAP, and PR dissolved, but in September of the same year, a new opposition coalition, the Pakatan Harapan (Alliance of Hope: PH), was formed by DAP, PKR, and a new party Parti Amanah Negara (National Trust Party: Amanah), which was formed by a group of PAS defectors. Namely, the experience of the formation of the opposition coalition and electoral advances since the 1990s led to the emergence of the progressive PAS members, who were more pragmatically oriented towards electoral politics and took a moderate 
position on religious issues. Their rise within the PAS led to a split, but even after the collapse of PR, communication between the opposition parties was not disrupted, which enables to re-form a new coalition immediately.

The PH's victory in the 2018 general elections came about due to the simultaneous combination of other factors in the context of the defaulting of the opposition coalition's formation. There were many factors interlinked with each other that led to defections from support for the BN, such as Prime Minister Najib's corruption scandal, the defection of former Prime Minister Mahathir and others from UMNO and the formation of the new party and higher inflation. The opposition coalition $\mathrm{PH}$ functioned as a receptacle for such defections.

\section{Alternative Explanations for Opposition Challenges in Malaysia}

Many studies focusing on the rise of opposition parties and civil society in Malaysia have accumulated since the Reformasi in $1998 .{ }^{67}$ In particular, many scholars have been pointed out the importance of internal conflicts and splits in the UMNO as facilitators of the opposition parties' breakthroughs and coordination. ${ }^{68}$ As noted earlier, the cases of the 1990 general elections, 1999, and 2018 show their importance. However, there was no split before the 2008 general election, when BN gained fewer than two-thirds of the seats in Parliament for the first time. In the 2018 general elections, the Parti Pribumi Bersatu Malaysia (Malaysian United Indigenous Party), which was established by former Prime Minister Mahathir after he left UMNO, joined the already formed opposition coalition $\mathrm{PH}$ and thus did not mediate the coordination between the opposition parties. Therefore, the UMNO's split is a critical but not sufficient factor for opposition coordination. 
Another possible explanation for the rise of mass protests after 1998 might be that it was due to the loosening of regime repression. To be sure, both Mahathir's successors, Prime Minister Abdullah (2003-2008) and Najib (2008-2018), initially advocated an intention to advance political liberalization in response to the growing momentum of mass protests. However, substantive institutional reforms were incremental, especially in the latter part of Najib's administration, which was regressive in terms of liberalization. ${ }^{69}$ On the other hand, the government's actual responses to the protests are inconsistent with the stance of these regimes. In the Bersih rallies, police authority arrested hundreds to more than a thousand participants each time and used tear gas until 2012. Since 2015, however, there were no clashes between participants and police, and street protests became a "daily routine ${ }^{70}$ In sum, it is reasonable to interpret that the degree of regime repression did not change as a trend, but remained mostly constant.

Finally, there is a possible explanation that the peculiar factor of ethnic powersharing in Malaysia, rather than the institutional factor of repeated elections, moderated the opposition challenge. As Lijphart pointed to Malaysia before the 1969 ethnic riots that shut down Parliament and cited it as an example of consociational democracies, ${ }^{71}$ many scholars have discussed the power-sharing among ethnic groups as an important factor explaining the $\mathrm{BN}$ regime's long-term stability, not just resource distribution. Saravanamuttu argues that the majority Malay ruling party UMNO while emphasizing Malay dominance as "bumiputra" won elections for a long time by practicing "mediated communalism" rather than necessarily raising and realizing ethnically radical claims. ${ }^{72}$ Furthermore, Nakamura (2015) reveals that the BN had fixed election issues on ethnic policy because the aforementioned vote-pooling effect arose from the BN's moderate stance on ethnic policy, and the more radical the opposition party was, the easier the BN 
won. ${ }^{73}$ The BN's moderate position led to the opposition DAP and the PAS adopting radical positions on both sides of the spectrum in the ethnic policy. However, the BN's strategy of divide and fixed issues, in turn, encouraged the opposition parties to compromise their ethnic policies and to cooperate.

This ethnic background unique to Malaysia made it easier to surface the influence of elections as a political institution. Due to the structure mentioned above of party competition that had continued since the 1959 general elections, the ethnic policy was always the election issue and the task for opposition coordination. In other words, the $\mathrm{BN}$ issue fixation contributed to the control of another variable that could typically influence opposition cooperation, namely, election issues. It allowed the opposition parties to readily draw on the learning from past electoral experiences, making it easier for the effect of repeated elections to emerge. Consequently, the factor of ethnic powersharing in Malaysia does not negate the relevance of this paper's argument.

\section{Conclusion}

This paper constructed the mechanism of the effect of repeated elections in authoritarian regimes on opposition challenges and explained the case of mass protests and opposition coordination in Malaysia under the $\mathrm{BN}$ regime from independence to 2018. Previous research on the effects of repeated elections in authoritarian regimes has focused either on the stability effects of dictatorships as a strategy for regime survival or on the democratization effects of promoting political and social liberalization. However, the importance of opposition challenges, particularly in changing strategic options, has been overlooked. Therefore, this paper argues that, while repeated elections curb regime changes by mass protests, they promote opposition engagement in within-institutional 
politics and the formation of opposition coalitions. The case analysis of Malaysia showed that mass protests by oppositions moderated over a long time. Besides, the coalition formation became the default strategy of the opposition parties, encouraged by the long continuation of their coalition formation negotiations between the DAP and PAS and the moderating but expanding protests. Further research is needed to examine the external validity of the framework in this paper. Although this paper applied its theoretical framework to Malaysia's case, it is necessary to test whether the same effect can be found in other authoritarian regimes using cross-national statistical analysis.

\section{Notes}

1 Steven Levitsky and Lucan A. Way, Competitive Authoritarianism: Hybrid Regimes after the Cold War (New York: Cambridge University Press, 2010).

2 "Pro-Najib blog: Mkini 'duped' Dr M into attending Bersih4," Malaysiakini, Aug. 30, 2015. https://www.malaysiakini.com/news/310464 (accessed Mar.13, 2020)

${ }^{3}$ The plot covers the authoritarian regimes that existed between 1948 and 2018 in the dataset by Geddes et al., and uses each regime's survival duration there (Barbara Geddes, Joseph Wright, and Erica Frantz, "Autocratic Breakdown and Regime Transitions: A New Data Set," Perspectives on Politics 12, no. 02 (June 2014): 313-31, https://doi.org/10.1017/S1537592714000851.). The number of repeated elections counts the number of times an election held that met the following three conditions in National Elections across Democracy and Autocracy (NELDA) as elections with a minimum of competition; elections in which opposition parties are allowed to participate (NELDA3), two or more parties are legal (NELDA4), and voters are given a choice (NELDA5) (Susan D. Hyde and Nikolay Marinov, "Which Elections Can Be Lost?," Political Analysis 20, no. 02 (2012): 191-210, https://doi.org/10.1093/pan/mpr040.).

${ }^{4}$ See Emily Beaulieu, Electoral Protest and Democracy in the Developing World (Cambridge University Press, 2014); Valerie Bunce and Sharon L. Wolchik, "Favorable Conditions and Electoral Revolutions," Journal of Democracy 17, no. 4 (October 31, 2006): 5-18, https://doi.org/10.1353/jod.2006.0056; Ryan Shirah, "Electoral Authoritarianism and Political Unrest," International Political Science Review 37, no. 4 (September 1, 2016): 470-84, https://doi.org/10.1177/0192512115580185. 
5 See Lisa Blaydes, Elections and Distributive Politics in Mubarak's Egypt (Cambridge University Press, 2010); Jennifer Gandhi and Ellen Lust-Okar, "Elections Under Authoritarianism," Annual Review of Political Science 12, no. 1 (June 2009): 403-22, https://doi.org/10.1146/annurev.polisci.11.060106.095434; Beatriz Magaloni, Voting for Autocracy: Hegemonic Party Survival and Its Demise in Mexico (Cambridge: Cambridge University Press, 2006), https://doi.org/10.1017/CBO9780511510274.

6 See Francis Loh, "Developmentalism and the Limits of Democratic Discourse," in Boo Teik Khoo and Francis Loh ed., Democracy in Malaysia: Discourses and Practices (London; New York: Routledge, 2014), 19-51; Mavis Puthucheary and Norani Othman, Elections and Democracy in Malaysia (Bangi: Penerbit Universiti Kebangsaan Malaysia, 2005).

7 See James Chin, "Politics of Federal Intervention in Malaysia, with Reference to Sarawak, Sabah and Kelantan," The Journal of Commonwealth \& Comparative Politics 35, no. 2 (July 1, 1997): 96-120, https://doi.org/10.1080/14662049708447747; K.S. Jomo and Chong Hui Wee, "The Political Economy of Malaysian Federalism," Discussion paper (Helsinki: UNU-WIDER, 2002), https://www.wider.unu.edu/publication/political-economy-malaysian-federalism; Thomas Pepinsky, "Autocracy, Elections, and Fiscal Policy: Evidence from Malaysia," Studies in Comparative International Development 42, no. 1 (June 1, 2007): 136-63, https://doi.org/10.1007/s12116-007-9006-4.

${ }^{8}$ Hidekuni Washida, Distributive Politics in Malaysia: Maintaining Authoritarian Party Dominance, (London; New York: Routledge, 2018).

9 See James C. Scott, Weapons of the Weak: Everyday Forms of Peasant Resistance (Yale University Press, 2008); Amri Baharuddin Shamsul, From British to Bumiputera Rule: Local Politics and Rural Development in Peninsular Malaysia (Institute of Southeast Asian Studies, 1986); Meredith L. Weiss, "Payoffs, Parties, or Policies: 'Money Politics' and Electoral Authoritarian Resilience," Critical Asian Studies 48, no. 1 (January 2, 2016): 77-99, https://doi.org/10.1080/14672715.2015.1126139.

10 See Mohd Azizuddin Mohd Sani, "Media Freedom in Malaysia," Journal of Contemporary Asia 35, no. 3 (January 1, 2005): 341-67, https://doi.org/10.1080/00472330580000201; Tsukasa Iga, "Kyoso teki Kenishugi Taisei ka no Malaysia ni okeru Hantaisei actor to Alternative media: Aliran Monthly to Harakah no Jirei kara[The Opposition Actors and Alternative Media in Competitive Autrhoritarianism Malaysia: The Case of Aliran Monthly and Harakah]," Kokusai Kyoryoku Ronshu 19, no. 1 (July 2011): 113-138; Jason Abbott and John Wagner Givens, "Strategic Censorship in a Hybrid Authoritarian Regime? Differential Bias in 
Malaysia's Online and Print Media," Journal of East Asian Studies 15, no. 3 (December 2015): 455-78, https://doi.org/10.1017/S1598240800009140.

11 Loh, "Developmentalism and the Limits of Democratic Discourse."

12 See Staffan I. Lindberg, "The Surprising Significance of African Elections," Journal of Democracy 17, no. 1 (2006): 139-51, https://doi.org/10.1353/jod.2006.0011; Staffan I. Lindberg, Democracy and Elections in Africa (JHU Press, 2006); Jan Teorell and Axel Hadenius, "Elections as Levers of Democratization: A Global Inquiry," in ResearchGate, Democratization by Elections: A New Mode of Transition, 2009; Carolien Van Ham and Staffan I. Lindberg, "Elections: The Power of Elections in Multiparty Africa," in Nic Cheeseman ed., Institutions and Democracy in Africa: How the Rules of the Game Shape Political Developments (Cambridge: Cambridge University Press, 2018), 213-37, https://doi.org/10.1017/9781316562888.009.

13 Meredith Weiss, Protest and Possibilities: Civil Society and Coalitions for Political Change in Malaysia (Stanford University Press, 2006).

14 Ibid, 43.

15 Ibid, 5.

16 See Ayako Masuhara and Ayame Suzuki, "Futatsu no Reformasi: Indonesia to Malaysia ni okeru Minshuka Undou to Taisei no Tenkan/Hi-tenkan [The Two Reformasi: Democratic Movements and Regime (Un)Transition in Indonesia and Malaysia]," Annals of the Japan Association for Comparative Politics 16 (2014), 227; and Weiss 2006, 43.

17 Michael Bernhard, Amanda B. Edgell, and Staffan I. Lindberg, "Institutionalising Electoral Uncertainty and Authoritarian Regime Survival," European Journal of Political Research 59, no. 2 (2020): 465-87, https://doi.org/10.1111/1475-6765.12355. 0

18 See Adam Przeworski, "Self-Enforcing Democracy," The Oxford Handbook of Political Economy, June 19, 2008, https://doi.org/10.1093/oxfordhb/9780199548477.003.0017; James D. Fearon, “SelfEnforcing Democracy," The Quarterly Journal of Economics 126, no. 4 (November 1, 2011): 1661-1708, https://doi.org/10.1093/qje/qjr038; Barry R. Weingast, “The Political Foundations of Democracy and the Rule of the Law," American Political Science Review 91, no. 2 (June 1997): 245-63, https://doi.org/10.2307/2952354; and Bernhard et al..

19 Blaydes, Elections and Distributive Politics in Mubarak's Egypt.

${ }^{20}$ Fearon, "Self-Enforcing Democracy."

21 Ellen Lust-Okar, Structuring Conflict in the Arab World: Incumbents, Opponents, 
and Institutions (Cambridge: Cambridge University Press, 2005), https://doi.org/10.1017/CBO9780511491009.

22 See Daron Acemoglu, Tarek A. Hassan, and Ahmed Tahoun, "The Power of the Street: Evidence from Egypt's Arab Spring," The Review of Financial Studies 31, no. 1 (January 1, 2018): 1-42, https://doi.org/10.1093/rfs/hhx086; Timothy Frye and Ekaterina Borisova, "Elections, Protest, and Trust in Government: A Natural Experiment from Russia,” The Journal of Politics 81, no. 3 (July 1, 2019): 820-32, https://doi.org/10.1086/702944.

23 See Marc Morjé Howard and Philip G. Roessler, "Liberalizing Electoral Outcomes in Competitive Authoritarian Regimes," American Journal of Political Science 50, no. 2 (2006): 365-81, https://doi.org/10.1111/j.1540-5907.2006.00189.x; Michael Wahman, "Offices and Policies - Why Do Oppositional Parties Form Pre-Electoral Coalitions in Competitive Authoritarian Regimes?," Electoral Studies 30, no. 4 (December 1, 2011): 642-57, https://doi.org/10.1016/j.electstud.2011.05.009; Michael Wahman, "Opposition Coalitions and Democratization by Election," Government and Opposition 48, no. 1 (2013): 3-32; Daniela Donno, "Elections and Democratization in Authoritarian Regimes," American Journal of Political Science 57, no. 3 (July 1, 2013): 703-16, https://doi.org/10.1111/ajps.12013.

24 Jennifer Gandhi and Ora John Reuter, "The Incentives for Pre-Electoral Coalitions in Non-Democratic Elections," Democratization 20, no. 1 (January 1, 2013): 137-59, https://doi.org/10.1080/13510347.2013.738865.

25 Yuko Sato and Michael Wahman, "Elite Coordination and Popular Protest: The Joint Effect on Democratic Change,” Democratization 26, no. 8 (November 17, 2019): 141938, https://doi.org/10.1080/13510347.2019.1645127.

26 Levitsky and Way, Competitive Authoritarianism.

27 This paper assumes that dissidents take either or both means of participating in elections or organizing protest movements. Other means may include boycotts (See Megan Hauser, Electoral Strategies under Authoritarianism: Evidence from the Former Soviet Union (London: Lexington Books, 2019), which we consider a means of coordination and challenge in the transition from the protest movement to elections. There may be some opposition parties that do not aim to change the government and believe that it would be more beneficial for them to be co-opted by the incumbent government to get a share of the pie, but in any case, if they do not win seats in Parliament, the incumbent government will not recognize them as worthy of being rewarded.

28 See Gary C. Jacobson, "Strategic Politicians and the Dynamics of U.S. House 
Elections, 1946-86," American Political Science Review 83, no. 3 (September 1989): 773-93, https://doi.org/10.2307/1962060; John Duggan, "Repeated Elections with Asymmetric Information," Economics \& Politics 12, no. 2 (2000): 109-35, https://doi.org/10.1111/1468-0343.00071; Dan Bernhardt et al., "On the Benefits of Party Competition," Games and Economic Behavior, Special Section In Honor of David Gale, 66, no. 2 (July 1, 2009): 685-707, https://doi.org/10.1016/j.geb.2008.10.007; Insun Kang, "Strategic Challengers and the Incumbency Advantage," American Studies 41 (2018), http://s-space.snu.ac.kr/handle/10371/147085.

29 See Carew Boulding, NGOs, Political Protest, and Civil Society (Cambridge: Cambridge University Press, 2014), https://doi.org/10.1017/CBO9781107588561; Thad Dunning, "Fighting and Voting: Violent Conflict and Electoral Politics:," Journal of Conflict Resolution, March 30, 2011, https://doi.org/10.1177/0022002711400861;

Carlos Scartascini and Mariano Tommasi, "The Making of Policy: Institutionalized or Not?," American Journal of Political Science 56, no. 4 (2012): 787-801, https://doi.org/10.1111/j.1540-5907.2012.00591.x. 2

30 Peter L. Lorentzen, "Regularizing Rioting: Permitting Public Protest in an Authoritarian Regime," Quarterly Journal of Political Science 8, no. 2 (February 25, 2013): 127-58, https://doi.org/10.1561/100.00012051.

31 Guillermo Trejo, "The Ballot and the Street: An Electoral Theory of Social Protest in Autocracies," Perspectives on Politics 12, no. 2 (2014): 332-52. (Trejo 2014)

${ }^{32}$ R. K. Vasil, Ethnic Politics in Malaysia (Radiant, 1980).

33 "Labour Party members in incident outside polls counting centre in Kuala Lumpur," The Straits Times, May 11, 1969, 4.

34 Yoshiki Kaneko, Malaysia no Seiji to Ethnicity: Kajin Seiji to Kokumin Togo [Politics and Ethnicity in Malaysia: Chinese Politics and National Integration] (Koyo Shobou, 2001), 200.

35 Rocket, April / May. 1968, 2.

36 Rocket, May / June. 1972, 7, 12.

37 Democratic Action Party, 25 Years of Struggle: Milestones in DAP History (Petaling Jaya: Democratic Action Party, 1991).

38 “P.M. to Pressure groups Don't cause disruption," New Straits Times, Nov. 15, 1985. "Public-interest groups abhor violence: Aliran," The Star, Dec. 23, 1986.

39 Rikuo Kimura, "Kyoko Toppa ga Shuzoku Tairitsu wo Yuuhatsu [Forced breakthrough evoked the race conflict: 1987 Malaysia]," in Ajia Doko Nenpo (IDEJETRO, 1988), 349-80, http://hdl.handle.net/2344/00002084, 356.

40 Internal Security Act (1960) was a law that allowed for preventive detention without 
warrant or trial, which was in force until 2011.

${ }^{41}$ Kural, "Peaceful People Power: Amazing outpouring of support as a sea of humanity floods Dataran Merdeka," Aliran Monthly 18, no. 9, (1998): 20-22.

42 Masashi Nakamura, Power-Sharing: Taminzoku Kokka Malaysia no Keiken [PowerSharing: The Experience of Multiethnic Nation Malaysia] (Tokyo: Tokyo University Press, 2015), 319.

43 Ying Hooi Khoo, "Mobilization Potential and Democratization Processes of the Coalition for Clean and Fair Elections (Bersih) in Malaysia: An Interview with Hishamuddin Rais," ASEAS - Österreichische Zeitschrift Für

Südostasienwissenschaften 7, no. 1 (2014): 111-20, https://doi.org/10.14764/10.ASEAS-2014.1-8, 115.

44 Ying Hooi Khoo, "The NGO-Government Relations in Malaysia: Historical Context and Contemporary Discourse," Malaysian Journal of Democracy and Election Studies 1, no. 1 (2013): 76-85.

45 Marina Mahathir. “My Bersih 2.0 experience," In Nathaniel Tan eds., Kisah Sebenar 9 July 2011 what really happened, (Kuala Lumpur: Kinibooks, 2011).

46 Khoo 2014, 116.

47 Tsukasa Iga, "Kassei ka shita Shakai Undou to Simin Shakai no Henbo: Bersih Undou ni yoru Gaito Demo no Nichijo ka [Social Movement Activation and Civil Society Change: Dailyization of Street Demonstrations by the Bersih Movement]," In Masashi Nakamura and Kumagai Satoru eds., Post Mahathir jidai no Malaysia [Malaysia in Post-Mahathir era] (IDE-JETRO, 2018), 173-222, http://hdl.handle.net/2344/00050282, 212.

48 Donald L. Horowitz, "Making Moderation Pay: The Comparative Politics of Ethnic Conflict Management," in Joseph V. Montville ed., Conflict and Peacemaking in Multiethnic Societies, (New York: Lexington Books, 1991), 451-76.

49 Nakamura.

50 Nakamura, p123.

51 “'S'pore denies polls 'aid' charges," The Straits Times, May 7, 1969, 1. The DAP is the successor to the Malayan branches of the PAP before Singapore's independence.

52 R.K. Vasil, The Malaysian General Election of 1969 (Oxford University Press, 1972), 28-29.

53 "Tengku: Why we ordered some S'poreans to leave," The Straits Times, May. 1, 1969, 1.

54 Nakamura, 124.

55 "Two parties test the ground on electoral pacts," The Straits Times, Feb. 2, 1981, 19. 
56 "Young Turks changing the communal stance of PAS," The Straits Times, April 20, $1981,14$.

57 “DAP ready to form united front, says Kit Siang," The Straits Times, Sep. 2, 1981, 14.

58 Ming Chee Ang, Institutions and Social Mobilization: The Chinese Education Movement in Malaysia, 1951-2011 (Institute of Southeast Asian Studies, 2015), 110.

59 Rikuo Kimura, "Sei-Kei Ryomen no Sai-Chosei: 1986 nen no Malaysia

[Realignment of Both Politics and Economcs]" in Ajia-Chuto Doko Nenpo (IDEJETRO, 1987), 321-52, http://hdl.handle.net/2344/00002030, 338.

60 "DAP 'strongly rejects idea of Islamic state'," The Straits Times, March 13, 1990, 16.

61 Rocket, June 1999, 10.

62 Rocket, June 1999, 11.

63 Masuhara and Suzuki 2014, 223.

${ }^{64}$ Masashi Nakamura and Rika Nakagawa, "Dokuritsu 50 Shunen ni Aratamete Minzoku kan Kankei ga Towareru: 2007 nen no Malaysia [50 ${ }^{\text {th }}$ Anniversary of Independence Raises Question of Inter-Ethnic Relations]," In Ajia Doko Nenpo, (IDEJETRO, 2017) 325-352, http://hdl.handle.net/2344/00002614, 333.

65 Boo Teik Khoo, "Borne by Dissent, Tormented by Divides: The Opposition 60 Years after Merdeka," Southeast Asian Studies 7, no. 3 (2018): 471-91.

${ }^{66}$ Hudud is a punishment regulated in the Qur'an and Hadith, with sentences such as stoning, flogging and dismemberment for charges, such as adultery, drunkenness and theft.

${ }^{67}$ See Jennifer Gandhi and Elvin Ong, "Committed or Conditional Democrats? Opposition Dynamics in Electoral Autocracies," American Journal of Political Science 63, no. 4 (2019): 948-63, https://doi.org/10.1111/ajps.12441; Andreas Ufen, "Opposition in Transition: Pre-Electoral Coalitions and the 2018 Electoral Breakthrough in Malaysia," Democratization 27, no. 2 (February 17, 2020): 167-84, https://doi.org/10.1080/13510347.2019.1666266; and Khoo BT.)

68 See Ong Kian Ming, Malaysian Political Parties and Coalitions, ed. Meredith L. Weiss (Abingdon, England; New York, NY: Routledge Handbooks, 2014), https://doi.org/10.4324/9781315756240.ch2; Kai Ostwald and Steven Oliver, "Four Arenas: Malaysia's 2018 Election, Reform, and Democratization," Democratization 27, no. 4 (May 18, 2020): 662-80, https://doi.org/10.1080/13510347.2020.1713757.

69 Ayame Suzuki "Seiji no Jiyu ka to Leader no Seizon: 2015 nen Sendo hou Shusei houan wo chushin to shita Houseido Kaikaku no Bunseki [Political Liberalization and the Leader Survival: an Analysis of Legal Reform with a Focus on the 2015 Sedition 
Act Amendment Bill]," In Masashi Nakamura and Kumagai Satoru eds., Post Mahathir jidai no Malaysia [Malaysia in Post-Mahathir era] (IDE-JETRO, 2018), 139-171, http://hdl.handle.net/2344/00050281, 140.

70 Iga 2018.

71 Arend Lijphart, Democracy in Plural Societies: A Comparative Exploration (New Haven: Yale University Press, 1977),

https://yalebooks.yale.edu/book/9780300024944/democracy-plural-societies.

72 Johan Saravanamuttu, Power Sharing in a Divided Nation (Institute of Southeast Asian Studies, 2016).

73 Nakamura. 